\title{
The Struggle over Ownership: How the Reform of State-owned Enterprises Changed China
}

\author{
CARL E. WALTER
}

\begin{abstract}
Events in the 1980s became the driving force behind state-owned enterprise (SOE) restructuring in the 1990s and beyond. In particular, the 1992 decision to seek listings for state-owned enterprises overseas had a tremendous impact on China's politics, economy and society. It may have been inevitable that the financial surgery on state enterprises would have serious social consequences. The assumptions behind this effort to create national champions, however, also defined the limitations on the Chinese government's response to the 2008 global financial crisis that broke out on the thirtieth anniversary of the 'reform and opening' policy. While SOE reform may not be the single most important determinant of how China has developed, it has had a unique directional impact by implanting the core of the Western financial system inside the Chinese state. This paper seeks to briefly review the evolution of corporate reform and show how Western capitalism has made its broader impact.
\end{abstract}

Keywords: SOE reform, national champion, shareholding, public listings, social security

\section{Introduction}

In 1978 China traded political revolution and social chaos for economic development under the slogan of 'reform and opening'. Here 'reform' suggested modernizing the country's economy while 'opening' referred to actively engaging the outside world in ways that would benefit the country. These two policy aspects can be seen to come together in the policies encouraging China's state-owned enterprises (SOE) to absorb new technologies and skills from their foreign competitors, or 'partners', so as to increase production efficiency, product quality and ultimately, international competitiveness. Events in the long-forgotten 1980s combined to be the driving force behind SOE restructuring in the 1990s. This effort had a tremendous and in many ways unexpected impact on the development of China's politics, economy and society. Moreover, 
the approach taken to SOE reform largely defined the limitations of the government's response to the global financial crisis that broke out on the thirtieth anniversary of the reform and opening policy itself in December 2008 (see Walter and Howie 2006: Chapter 9). While SOE reform may not be the single most important determinant of how China has changed over these 30 years, it has had a uniquely significant directional impact. This paper seeks to briefly review the evolution of corporate reforms over this period. By doing so it suggests just how important this path has been to bringing China to the year 2009 when the country faces perhaps its greatest challenge since determining how to move forward after the Cultural Revolution gasped to a close.

Why such a huge challenge now in 2009? It is not simply because there is a major financial crisis. China has gone through major political, currency and market crises since 1978 and continued to move rapidly ahead economically. This time is different, however, since the crisis has seemed to discredit the financial model China adopted to guide its reforms. While Deng enjoyed saying that China has gone from stone to stone to cross the river, those stones were not previously untrodden. What model? There is no doubt that - and all one has to do is look around China's rich coastal cities to see this - from the start China saw the American Superhighway to Capital as the fastest way to get rich; the Olympic Summer of 2008 represented the very apogee of its adaptation of this model. Perhaps the sixtieth anniversary military parade represents its new direction.

On this highway China has passed through four stages on its route to American capitalism Chinese-style. Figure 1 suggests how China has largely pursued reform and opening in line with the American path toward financial deregulation. It may feel strange for those who work in China and struggle each day with the Chinese regulatory system to consider that the government has deregulated its markets. Nonetheless, there can be no doubt that on a relative basis China has a far more liberal and open economic system than it began with in 1978. At that time there was no banking system, no stock markets, no private (non-state) sector and very few foreigners struggling against anything.

\section{Stage 1: 1978-1992}

In Stage 1, roughly the years from 1978 to 1991, the reform and opening policy came to focus on state-owned enterprises (see Wu Jinglian 2003: Chapters 2 and 8) and the creation of special economic development zones (SEZ) where joint ventures (JV) between SOEs and foreign com- 
panies could be established (see Lardy 1992; Huang 2003). In 1980, four coastal cities (Shenzhen, Zhuhai, Shantou in Guangdong and Xiamen in Fujian) were designated SEZs and special policies were enacted to attract foreign investment; in 1984, this so-called 'open-door policy' was extended to 14 coastal cities including Dalian, Qinghuangdao,Tianjin, Yantai, Qingdao, Lianyungang (Liaoning), Nantong, Shanghai, Ningbo, Wenzhou, Fuzhou, Guangzhou, Zhanjianj (Guangdong) and Beihai. From 1988 Hainan Province was designated an SEZ while the original four had their areas enlarged, creating vast open spaces in the Yangtze and Pearl River Deltas, Fujian and the Shandong and Liaodong Peninsulas. Finally, the Shanghai Pudong New Area was approved in 1990 to become the 'Dragon's Head' of the Yangtze River valley. This more or less marked the end of laying out special areas for foreign investment; the entire country was thrown open to it during the 1990s.

FIGURE 1: Thirty Years of Reform: Trends in Deregulation

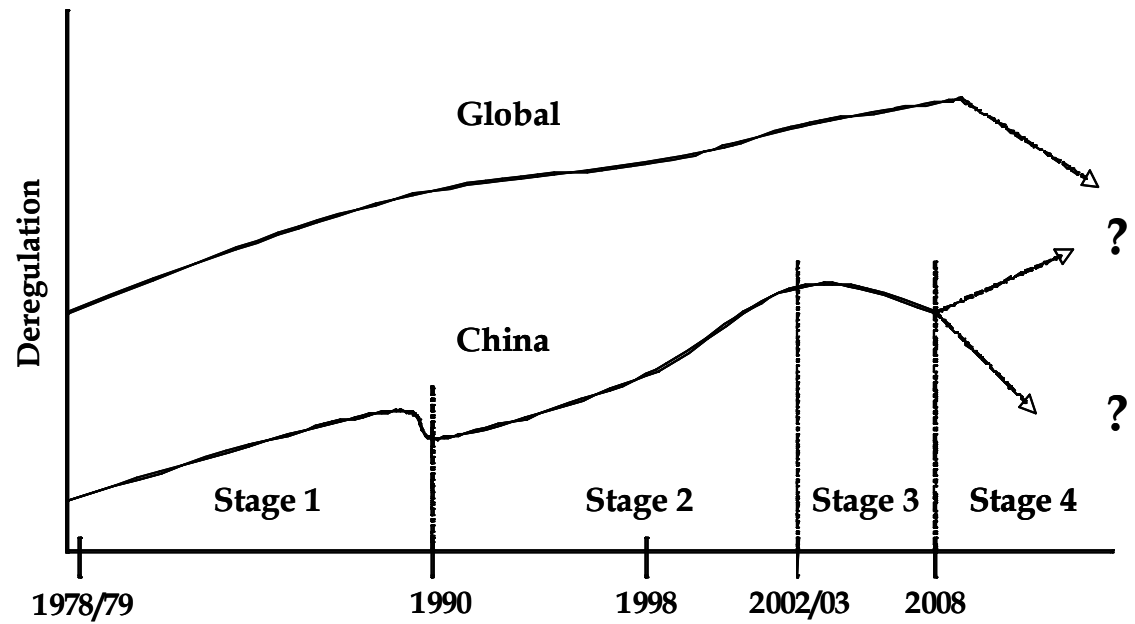

Source: Based on Peter Nolan, comments, Copenhagen Business School, 4 December 2008.

The objective of this massive opening, at least at the outset, was to benefit the SOEs. It was thought that these enterprises, through the absorption of new technologies and skills from their foreign competitors, that is to say, JV partners, would become more efficient and competitive. The famous Beijing Jeep joint venture of the mid-1980s was the largest of these and might be taken as an emblem of the various difficulties associated with this effort. Here the Chinese side typically contributed land, buildings and equipment as its capital contribution to the JV while the foreign partner brought in money, equipment and modern technologies (Figure 2). 
The problem with JVs has always been summed up by the famous saying 'same bed, different dreams'. In short, although some have worked out, these corporate forms are not the most desirable and effective for either side. JVs created friction between the partners, hampering the hoped-for transfer of experience and technology and making profitability an elusive goal. Even worse, it was not a particularly effective way to draw foreign investment: through 1992 only US\$20 billion had been committed. But even though the JV was not a successful structure, it was the opening of the SEZs themselves that has had long-lasting consequences that would only become clear in the new century.

FIGURE 2: Sino-Foreign Joint Venture

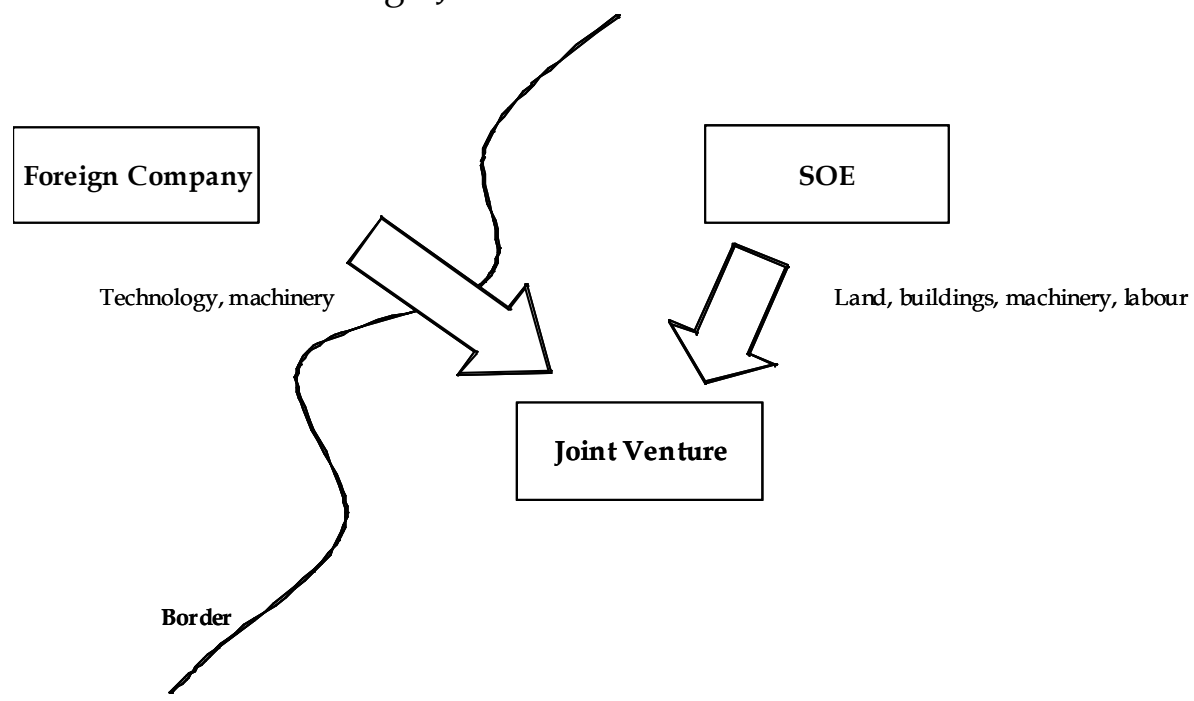

A second effort toward SOE reform was also begun in late 1978 in Sichuan. There the provincial government, led by future party secretary Zhao Ziyang, launched a pilot project to expand management autonomy in six selected enterprises (Wu Jinglian 2003: 138-39). These six SOEs contracted to produce a certain amount of goods according to the state plan; any production beyond that could be sold by the SOE with these revenues accruing to it alone. These funds would, theoretically, then be used to acquire advanced technologies to upgrade the SOE's capabilities or incentivize workers and staff by increasing compensation (Figure 3).

In July 1979 the State Council deemed this initial trial a success and ordered it expanded across the country; by year-end some 4,200 provincial-level enterprises were involved. Then, in 1980, some 6,600 large- and medium-sized SOEs, accounting for 60 percent of national 
FIGURE 3: SOEs Operating under Contract Responsibility System

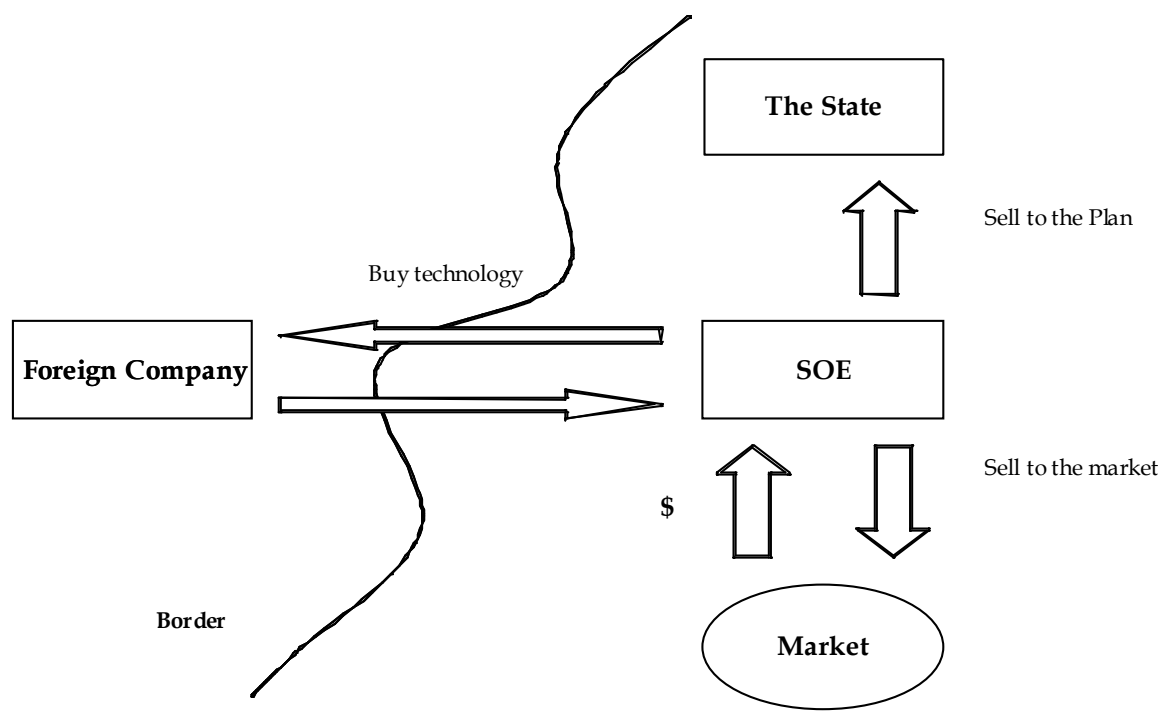

industrial output and 70 percent of national industrial profit, joined the reform program (Wu Jinglian 2004). Over the course of the 1980s the autonomy of these enterprises grew stronger and relations with the government increasingly became based on contracts rather than plans. This overall program became known as the contract responsibility system. In contrast to the JV initiative, the SOE remained as it was; there was only a transactional trading relationship with the foreign party if any existed at all.

This reform had significant and far-reaching consequences. By establishing an enterprise's legal rights to certain monies and the assets acquired with them, the balance of power between the state and senior enterprise management began to shift in favor of the latter. As one SOE boss said, 'It doesn't matter who the money belongs to, it matters who gets to use it!' The SOEs operating under the contract responsibility system can be seen as the harbingers of the huge business groups that gained tremendous political influence later in the 1990s. Beijing's Capital Iron \& Steel and its famous chairman, Zhou Guanwu, were perhaps the most famous representatives of this line of reform. It was not surprising that Zhou and his son, Zhou Dongfang, were beaten down by the central government in the early 1990s when the latter still retained the upper hand against its own enterprises. This was a tragedy of epic proportion as the true founder of that huge enterprise on Beijing's western edge was forced into retirement, his son thrown in jail and the enterprise itself, a steel maker producing ten million tons a year, was driven out of town 
to enable Beijing to claim a 'green' Olympics in 2008 (see Nolan 2001: Part 1 for many more such stories). How times change.

FIGURE 4: Collective Stock Enterprise

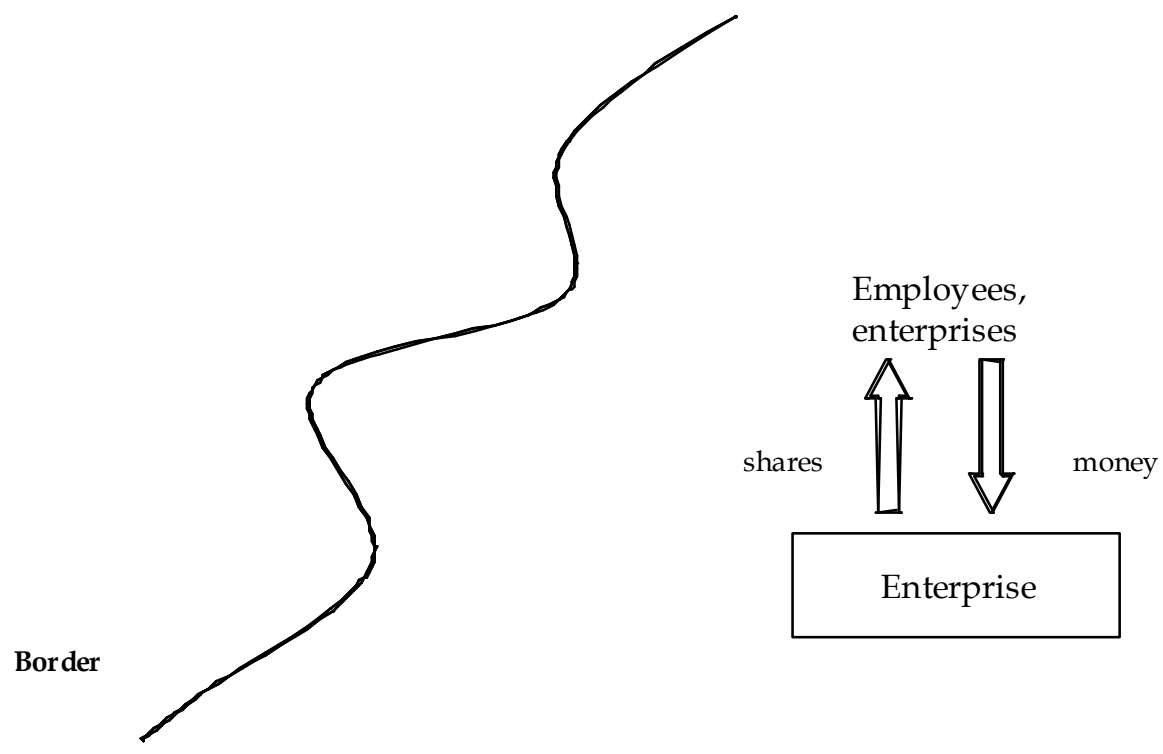

These, then, were the two mainstream corporate reform efforts of the 1980s. There was, however, a third experience that developed tremendous momentum during the decade: small enterprises issuing shares (or something like them; see Figure 4). On 3 July 1979, the State Council gave the initial go-ahead for what was already a spontaneous practice saying, 'It is permitted to take an appropriate amount of funds from the brigade or production group's common accumulated funds to put in as (start-up) equity $(g u)^{\prime}$ (Wu Xiaoling 2008: 18). This unheralded sentence kicked off an experiment deep in the countryside on the extreme fringe of the economy that over the past 30 years has became one of the two principal driving forces creating the China of 2008.

From 1978 to 1983, the number of what became known as 'collective stock enterprises' (gufen hezuo qiye) grew (Liu Hongru 2008: vol. 1: 156). The early pioneers included such standouts as the Liaoning Fushun No. 1 Red Brick Factory, Shanghai Feile Acoustics, the Chengdu Shudu Building, the Shenzhen Baoan Joint Stock Investment Company and the Beijing Tianqiao Department Store-each a pretender to the claim of being the first to issue shares. The Communist Party's famous 1984 'Decision on the Reform of the Economic System' provided the official imprimatur for this development and by late 1986 the number of such enterprises had reached 6,000 to 7,000 nationwide, raising altogether 
around RMB6 billion (Liu Hongru 1992), at the time a lot of money and all outside of any state plan. The central government had all along indicated, at times obliquely, its general support of this capitalist practice. This positive attitude was perhaps best symbolized by Deng Xiaoping's meeting with the Chairman of the New York Stock Exchange in the Great Hall of the People in November 1986.

If things had simply remained at a local level and involved only small enterprises raising small money there would be no story. But someone started to think big and in 1986 the Shenzhen government, with a bow to Hong Kong, produced the first regulations standardizing the process by which enterprises could be reorganized as shareholding companies (Jiang Ping 1997: vol. 2, 2815-18). The 1986 Shenzhen Provisions represent the first effort to systematize and standardize procedures relating to the restructuring of enterprises into shareholding companies. One wonders what the balance sheets looked like in the share-issuing enterprises prior to 1986 (for a look, see Walter and Howie 2006: 69-73).

The main characteristic of these provisions was their liberalism. Although they were directed primarily at the restructuring of the Shenzhen's own SOEs, the government welcomed all enterprises to use them as a guide. In addition to other domestic enterprises and individuals, foreign investors were also permitted to acquire shares in restructured SOEs by buying either existing shares from the government or newly

FIGURE 5: Creation of a Company Limited by Shares

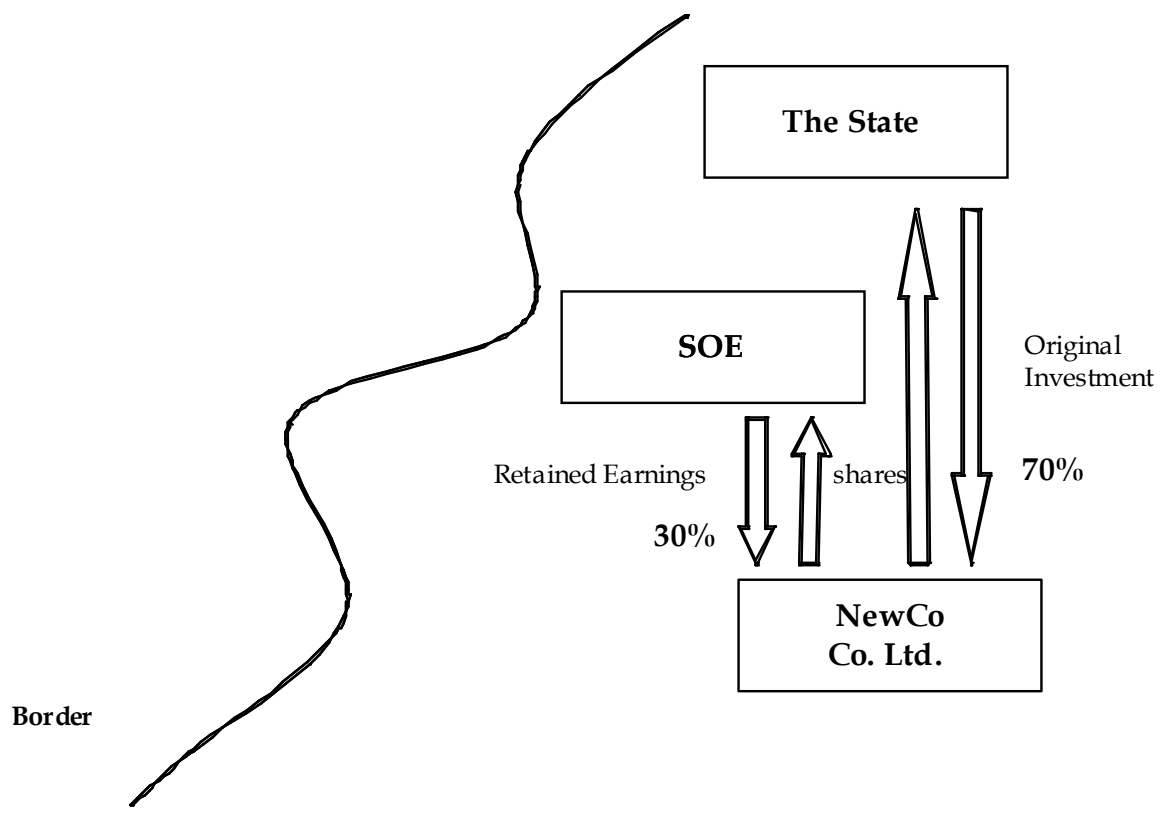


issued shares (see Figure 5). Restructured SOEs were permitted to sell shares overseas and banks could hold shares as either loan collateral or as part of a debt-for-equity swap. Ownership of shares was closely defined and permitted the holder to sell, gift, inherit or use as loan collateral. Obviously influenced by Hong Kong laws, the Shenzhen Provisions suggest a possible outcome different from that adopted by the State Council following the Tiananmen incident. Even today, China's securities regulations have been unable to attain this level of sophistication.

What happened next when these provisions were applied can be clearly seen in the five types of companies that used them: 1) smallSOEs soliciting investment from the state, other enterprises and individuals; 2) large SOEs that incorporated with a single state shareholder; 3) Sino-Foreign Joint Ventures restructuring as shareholding companies; 4) private companies; and 5) limited liability companies with multiple shareholders. All these companies underwent restructuring into shareholding companies only with the aim of raising money. Their actions were not driven by political need, only economics. The result of such capital raising in Shenzhen verged on outright privatization, as Table 1 illustrates.

TABLE 1: Shareholding Structure, National vs. Shenzhen (31 December 1991)

\begin{tabular}{|l|c|c|c|c|}
\hline Shareholder & National Sample & $\begin{array}{c}\text { State } \\
\text { per- } \\
\text { cent }\end{array}$ & Shenzhen Sample & $\begin{array}{c}\text { State } \\
\text { per- } \\
\text { cent }\end{array}$ \\
\hline State & 47 & 76 & 23 & 36 \\
\hline Enterprise & 29 & & 13 & \\
\hline Individual & 14 & & 27 & \\
\hline Foreigner & 9 & & 37 & \\
\hline
\end{tabular}

Source: Liu Hongru 1992; Gao and Ye 1991: 88.

Shenzhen was not isolated in its enthusiasm for this policy direction. Local governments across China at this time were actually sending in surveys of SOE bosses indicating, as might be expected, overwhelming support for the reform (Li Zhangzhe 2001: $113 \mathrm{ff}$ ). At this same time the State Committee for Restructuring the Economic System (SCRES) had prepared and sent to the State Council a draft regulation titled 'Pilot Method for Enterprises Carrying out the Shareholding System'. It was well received, but events of 1989 swept past it. 
Simultaneous with all this activity in the capital, in March 1989 the Shenzhen Development Bank (SDB), the first large state-owned enterprise to offer shares to the public in 1987, announced its first dividend. This single act changed China's post-revolution financial landscape forever. The bank's shareholders (mostly the government, so the motive for this dividend is clear) received a fat cash dividend as well as a twofor-one stock dividend. In the blink of an eye, all investors, including the moms and pops, enjoyed a profit several times their original investment. This was wonderful, but it was the negligence of a small number of shareholders who had failed to claim their new shares that changed everything. The bank had no choice but to auction these remnants off publicly. In an instant one individual appeared and bought the whole lot at several times the asked price. This news spread throughout Shenzhen like wildfire and armed with this new insight-shares were different than bonds! - investors set off a period of 'share fever' centred on Shenzhen and extending during 1990 (and despite June 4) to Shanghai (Cao Erjie 1994: 140 ff).

\section{Stage 2: 1992-1998}

The popular enthusiasm for the quick buck and attendant alleged 'social unrest' in the post-June 4 environment gave the conservative wing of the government the opening to develop regulatory controls in a bid to impose order. In May 1990 the State Council announced restrictions on the experiment (Liu Hongru 2003: 48-49; Walter and Howie 2006: 27-28; Li Zhangzhe 1997: 128-29). Of these there were two pivotal ones. First, the state hijacked the entire shareholding experiment: going forward only SOEs could experiment with share issuance. This decision was the defining moment in the development of China's capital markets reversing as it did the entire experience of the freewheeling 1980s. Henceforth, the story of China's experience with stock exchanges would not be about privatization and capital allocation, but rather financing troubled SOEs, moral hazard, corruption and speculation, lots of speculation (Yuan Jian 2004: 1-6). Second, Shenzhen and Shanghai were designated as the only officially recognized OTC trading markets, thereby excluding active exchanges in Shenyang, Chengdu, Wuhan, Beijing and Tianjin, all of which were gradually closed down. 


\section{Hijacking the Shareholding System}

Despite these restrictions, or perhaps because the experiment was now brought wholly within the bounds of the state system, the effort moved ahead. A decision was made at the same time to proceed with the formal establishment of the Shanghai and Shenzhen securities exchanges. Taken during the wild market conditions in the first half of 1990, the intent was to eliminate street markets and crowds by providing a controlled venue for securities trading in two administrative areas at the time well under the thumb of the central government. The prospect of having potentially disruptive securities exchanges located throughout the country, much less in Beijing, was politically unacceptable in the post-Tiananmen period. In the event, the Shanghai exchange opened in December 1990 and Shenzhen shortly after, in July 1991. But in both cases only the few companies that had publicly sold shares and a handful of government bond issues were listed and there were no plans to add to them. The exchanges were thus stillborn and the wild street scenes of the preceding years disappeared. This did not last long.

In early 1992 Deng Xiaoping took his now famous Chinese New Year trip, the so-called Southern Journey, to the SEZs in Guangdong. His comments made at various stops ended the political stasis that had frozen China in place since June 1989 and appeared to set free the innovative forces characterizing the 1980s. And change did move forward rapidly. Many commented that 1992 marked a return to Zhao Ziyang's policies of super-fast growth, but without Zhao, of course. It soon became clear, however, that in the 1990s capital markets change was going to be all about the state industrial sector. Moreover, it was not going to be about Western-style privatization, but about financing troubled SOEs and, as a side result, strengthening those who controlled them (Liu Hongru 2003: 51-54). It has only become clear now, more than 15 years later and against the backdrop of the purported 'collapse' of Anglo-Saxon-style financial capitalism, just how deeply this path has imperiled China and its much spoken of 'transition'. How did this happen?

\section{Ownership in a Communist State}

It happened because the shareholding reforms opened up the Pandora's box of 'ownership' (Cao Lan 2001: 16). Under the socialist planned economy, SOEs were held by the state on behalf of the 'whole people'. There were no clear ownership rights to SOEs (or anything else for that matter) under such a deliberately nebulous ideological proposition. When SOEs entered into JVs with foreign companies, explicit 
and legally binding ownership rights in the JV were created, but these rights were not fungible, they could not be easily transferred and sold and, moreover, the ownership of the SOE itself remained unaffected. Similarly, the contract responsibility system did nothing to change the structure of the SOE. It did, however, advance developments toward defining ownership in one very important way. The sale of product over and above the plan quota gave the SOE its own capital to invest as it desired outside the plan.

The value of this right became clear after China's first corporate law, the 'Standard Opinion', went into effect in 1992. Under the Opinion, companies limited by shares were created when a promoter contributed assets to the establishment of the NewCo and received share certificates in return (see Figure 6). The question became: who owned the assets contributed and, therefore, the shares? Thus was the lid to Pandora's box opened. Obviously, the state had invested in the establishment and development of the SOEs and owned them lock, stock and barrel. But, due to the contract responsibility system, some SOEs now also had their 'own' capital and assets. Of course, all was ultimately owned by the state, but it was a matter of what part of the state or just how directly. As time went on, what might have been seen as a quibble at the start became the mighty wedge that would undermine the government at all levels by creating the very foundation for pervasive corruption.

Assuming that the SOE contributed assets acquired with its own earnings, a NewCo, at its inception, could have at least two shareholders. From this point, the resulting multiplicity of owners (and the consequent differences in self-interest) began to confuse the very notion of the 'state'. But what was the point of creating NewCo and this confusion in the first place? The answer is straightforward and the same in all places in the world: an unquenchable thirst for capital. Local governments in the 1980s (as today) had extremely limited financing resources. Somehow the idea of stocks and stock markets had taken hold in the relaxed political environment following the Cultural Revolution. By 1988 these innovations were about to be memorialized by government laws and regulations and even in the institution of a stock exchange. Zhu Rongji, then the mayor of Shanghai, was the great proponent of stock markets (Li Zhangzhe 2001: $130 \mathrm{ff} ;$ Wang An 2000: 82-83). But stock markets without stock cannot exist, so corporatizing SOE assets was the requisite pre-condition to listing. The consequences of what was seen by the government as a technical detail to a straightforward financing transaction (no need to repay equity!) 
FIGURE 6: The Company Limited by Shares

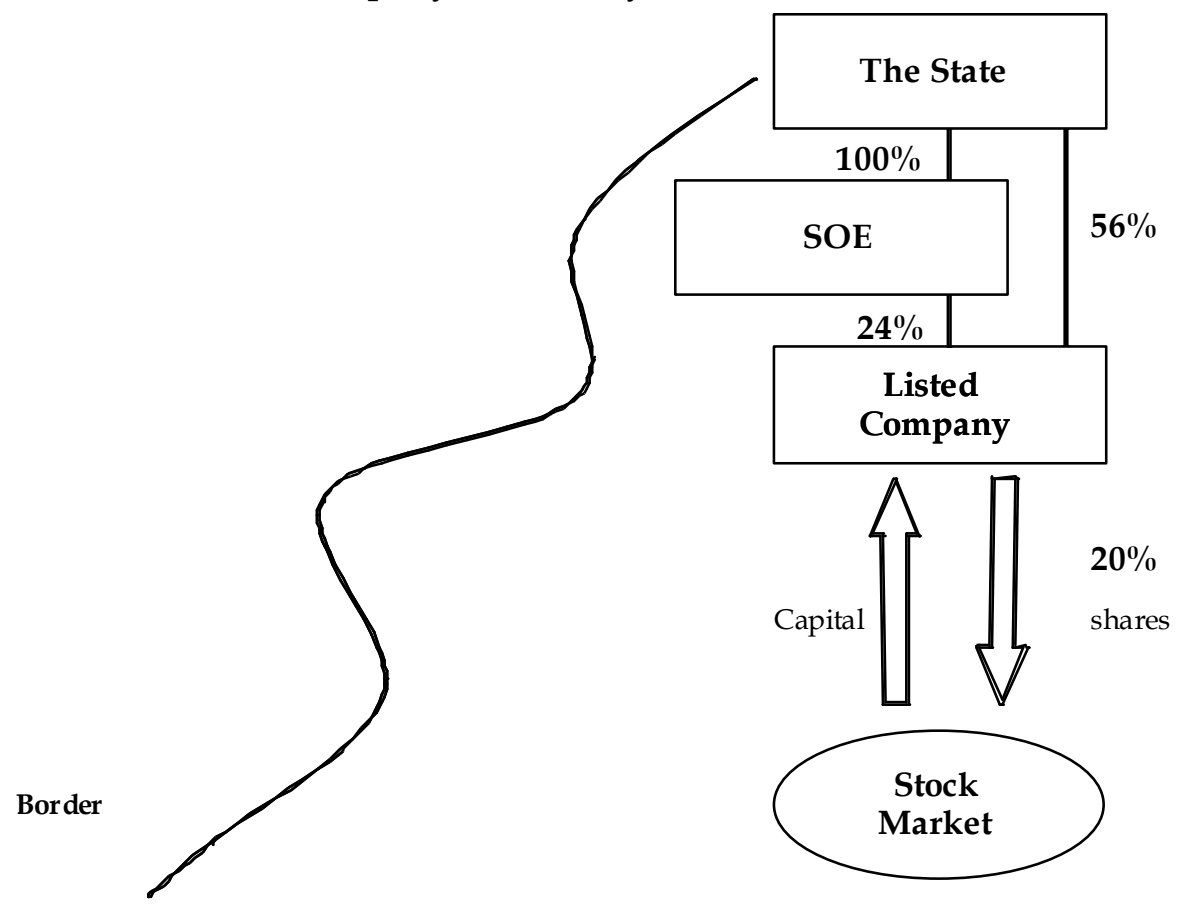

was, however, not foreseen, nor were the many beneficiaries desirous of having it foreseen!

The process of corporatization took the formally non-fungible assets (you couldn't readily swap a piece of machinery for cash) of the SOE, clarified their ownership, i.e., who paid for them originally, and in the first step issued very marketable share certificates in return to the contributors (or 'promoters' of NewCo). Legally defined ownership title had thus been created where before there had been none. As the SOE boss said, 'It doesn't matter ....'

\section{Internationalizing the Shareholding Experiment}

By itself all this might have been manageable if listing had taken place only on the domestic exchanges. It was the decision made in April 1992, once again by Zhu Rongji, now Vice-Premier, to list ten Chinese NewCos on the Hong Kong Stock Exchange (HKSE) that led to truly significant change: the rules of the game became foreign rules not Chinese rules (Liu Hongru 2008: 672). Of course, at this time the ability to have the 'face' gained by listing in Hong Kong or even New York, if possible, became the ultimate objective for all the major SOEs and their bosses. It is hard now to imagine the chaotic struggle that resulted to 
achieve this privilege; meanwhile the domestic markets were relegated to smaller, less politically connected enterprises (see Walter and Howie 2001: Appendix 25 for the list of connected candidates). But the foreign rules were, not unexpectedly, about value: what did investors get for their capital?

Listing shares on any stock exchange required companies to have their capital expressed in terms of numbers of shares of a certain value per share. This value as offered to third party investors is a function of the company's expected future profit growth potential. This was not so when listing on China's domestic exchanges; the Chinese Securities Regulatory Commission (CSRC) provided a formula based on earnings history and the one formula fit all companies. In short, the Chinese approach treated companies as commodities. But when it came to listing overseas, investment bankers required that a company have a positive earnings outlook for the next three years based on internationally accepted standards of valuation. The typical SOE had no such earnings profile. This was the rub: the SOEs listing domestically did not have to undergo a top-to-bottom restructuring in pursuit of a profitable core, but those listing internationally did (Figure 7). International investors, in short, had absolutely no interest in investing in Chinese social security arrangements.

Such a restructuring split the SOE into two basic pieces, the largest of which was naturally the old SOE portion. This piece now became known as the Group Company and included all non-operating assets, retirees

FIGURE 7: SOE Corporatization for International Listing

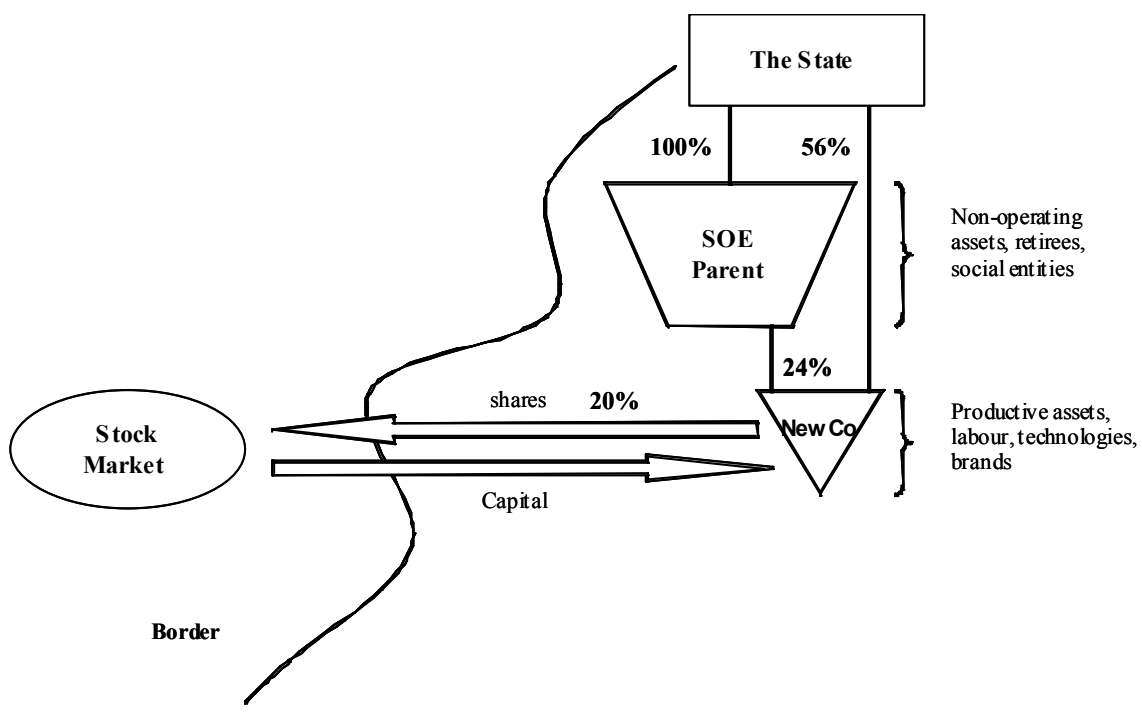


FIGURE 8: Industry Restructuring into a Single NewCo

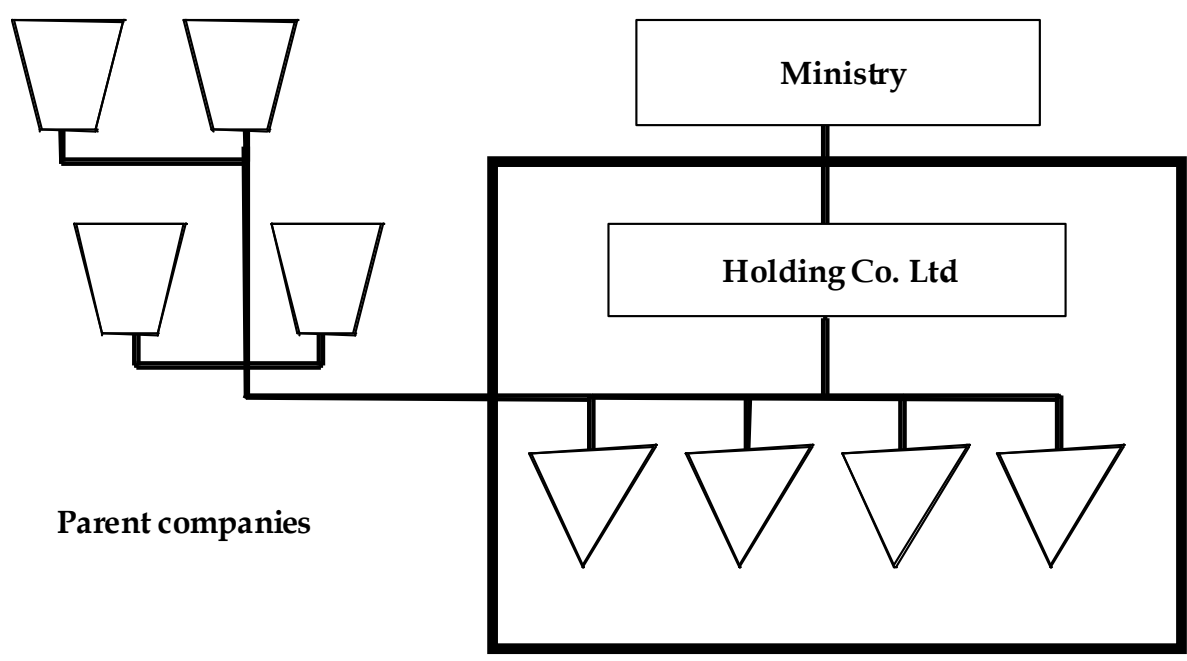

\section{New company}

and their families and all peripheral social entities (for example, fire and police, courts, travel agencies, hotels, restaurants), plus all unprofitable operating assets. This part, in effect, was the state social security system. The smaller part was the proposed NewCo. This comprised all the productive assets, labour, technologies, brands and so forth. Presumably this portion, modelled after similar already-listed companies in market economies, would be increasingly profitable. This type of restructuring is really a triumph of accounting, legal and tax advice and investment bank modelling and valuation. It was also a social disaster. Nevertheless, in 1994, with the signing of the Company Law (again by Zhu Rongji), the Chinese government indicated that corporatization and shareholding reforms would be the principal way forward for the SOEs.

\section{Social Welfare and Other Consequences}

It was a social disaster because, in the absence of anything else, it destroyed the SOE's core function as the provider of social security to the Chinese worker and his family. If the foundation of the Chinese state was social stability, the SOE was its cornerstone. From 1997, investment bankers began to chip away at this stone by using their financial magic on entire industries and out of their efforts arose China's national champions starting with the US $\$ 4.1$ billion IPO for China Telecom (now known as China Mobile; see Table 2). This success, plus the soon-to-break-out 
TABLE 2: National Champion Overseas IPOs, 1997-2005

\begin{tabular}{|c|c|c|c|}
\hline Company & Industry & Date & $\begin{array}{c}\text { IPO Size (in } \\
\text { billions of } \\
\text { US\$) }\end{array}$ \\
\hline China Mobile & Telecoms/mobile & 23 Oct. 1997 & 4.1 \\
\hline PetroChina & Oil and gas & 7 July 2000 & 2.9 \\
\hline China Unicom & Telecoms/mobile & 22 June 2000 & 5.1 \\
\hline Sinopec & Oil and gas & 19 Oct. 2000 & 3.3 \\
\hline $\begin{array}{l}\text { China National Off- } \\
\text { shore Oil }\end{array}$ & Oil and gas & 28 Feb. 2001 & 1.4 \\
\hline China Aluminum & Mining and processing & 12 Dec. 2001 & 0.5 \\
\hline China Telecom & Telecoms/fixed line & 8 Nov. 2002 & 1.4 \\
\hline China Life Insurance & Insurance & 18 Dec. 2003 & 3.4 \\
\hline Ping An Insurance & Insurance & 24 June 2004 & 1.8 \\
\hline Air China & Airlines & 15 June 2005 & 1.2 \\
\hline $\begin{array}{l}\text { China Shenhua } \\
\text { Energy }\end{array}$ & $\begin{array}{l}\text { Energy and } \\
\text { Power }\end{array}$ & 15 June 2005 & 3.3 \\
\hline $\begin{array}{l}\text { Bank of Communica- } \\
\text { tions }\end{array}$ & Banking & 23 June 2005 & 2.2 \\
\hline $\begin{array}{l}\text { China Construction } \\
\text { Bank }\end{array}$ & Banking & 27 Oct. 2005 & 9.2 \\
\hline Bank of China & Banking & 1 June 2006 & 11.1 \\
\hline Total Capital Raised & & & 50.9 \\
\hline
\end{tabular}

Source: Wind Information.

Asian financial crisis, further exacerbated the social problem: millions of workers were laid off and retirees suddenly left without sufficient pensions. Simply put, the cash flow of the newly listed company was now legally its property alone as a result of incorporation. The SOE parent became simply one of now many investors receiving dividend payouts, but these were insufficient to meet the social obligations of its greater enterprise.

The economic forces set loose by Western-style corporate restructuring led to significant consequences for China's government. First, in order to take care of jobless former state employees, the government had little choice but to begin experimenting with social security and medical 
insurance solutions (Xiang Huaicheng 2005). Second, to create the jobs that the state sector could not and to provide an interim social security net, the government, and especially the local governments, encouraged even more foreign investment. Third, the creation of industry-wide monopolistic companies, known as the national champions, created monopolistic economic power that came to threaten, if not supplant, the state itself. The rest of this paper describes how these special interest groups created by Western-style capital markets clashed with the government over the issue of funding social security.

\section{Stage 3: 1998-2002}

\section{Reforms of SOE Ownership and the Central Bureaucracy}

Over the course of the 1990s local enterprises, workers, mom and pop investors and local governments had seen their influence diminished and ultimately usurped by central government agencies, central state enterprises (the yangqi) and the financial sector, also largely owned by Beijing. With this decline in influence went a vast decrease in financial capacity at the local level. Although the 1994 tax reforms clarified those taxes that would be collected and kept by local governments, the 1998 collapse of Guangdong International Trust and Development Corporation (GITIC), led to the closure of all but 50 of the 400 trust companies owned by local governments (Li and Cao 2007: 443-79). These non-bank financial institutions had allowed localities to raise significant debt capital outside their approved budgets which, by law, were required to be balanced. This decline in extra-budgetary financial resources, combined with the impact of the Asian financial crisis, inevitably benefited the foreign-invested sector as local governments were driven to compete even more strongly for new foreign investment and consequent job creation and tax revenues.

The Asia financial crisis also compelled Premier Zhu Rongji to streamline the bloated central government bureaucracy. Despite strong resistance, Zhu succeeded in reducing the number of ministries from 41 to 29 , downsizing the State Council from 32,000 to 16,000 staff and eliminating a number of industrial ministries as well as the agency overseeing the management of state assets. The flip-side of this was the support he received from SOE groups which, with fewer and weaker 'grandmothers' overlooking their activities, now truly emerged as virtual kingdoms unto themselves. Their political influence grew in line with their financial 
FIGURE 9: Ownership Arrangements of State-owned Enterprises

1950-1998

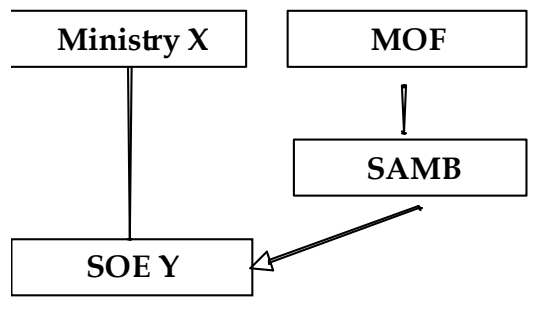

1998-2003

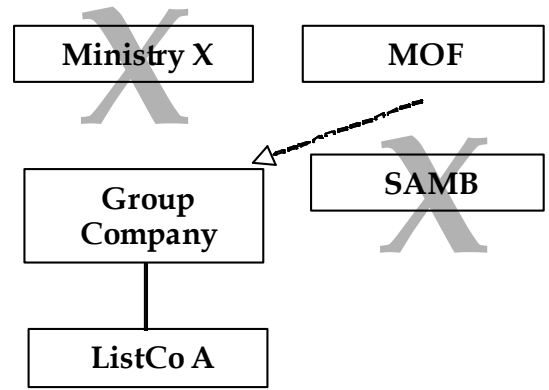

wealth. How could it be any different when the related senior ministry officials had parachuted into top positions of these groups; who knew the hot buttons of government better than they?

As illustrated by Figure 9, the State Asset Management Bureau (SAMB), an early forerunner of the State-owned Assets Supervision and Administration Commission (SASAC) and the agency of the Ministry of Finance (MOF) responsible for the oversight of SOEs, was eliminated in this restructuring. For the next five years all major decisions relating to ownership issues in the industrial sector owned by the central government were handled by a poorly manned office, the MOF Enterprise Office (qiye si). With this bureau and most industrial ministries gone, many SOEs became virtually autonomous with only the Party apparatus left to oversee them.

\section{Social Security}

Thus the pressure to build a viable social security system was driven by the form of corporate restructuring adopted by China as well as by the domestic impact of the Asian financial crisis (Garnaut et al. 2005: Chapter 4). Discussed since 1995, but put into effect in 1998, the 'seize the large, release the small' policy towards SOEs quickened the layoff of workers in the local SOE sector. Henceforth only the 500 largest SOEs, for the most part owned by the central government, would receive state support. The cash-strapped provincial and local governments, for their part, were forced to spin off their smaller SOEs into private hands in the hope that jobs would be retained if not increased.

But, obviously, a sound social security system is not simply a matter relevant to former SOE employees. China's population is rapidly aging. As Table 3 indicates, by the middle of the twenty-first century 
FIGURE 10: Committed Foreign Direct Investment, 1979-2007 (US\$ billion)

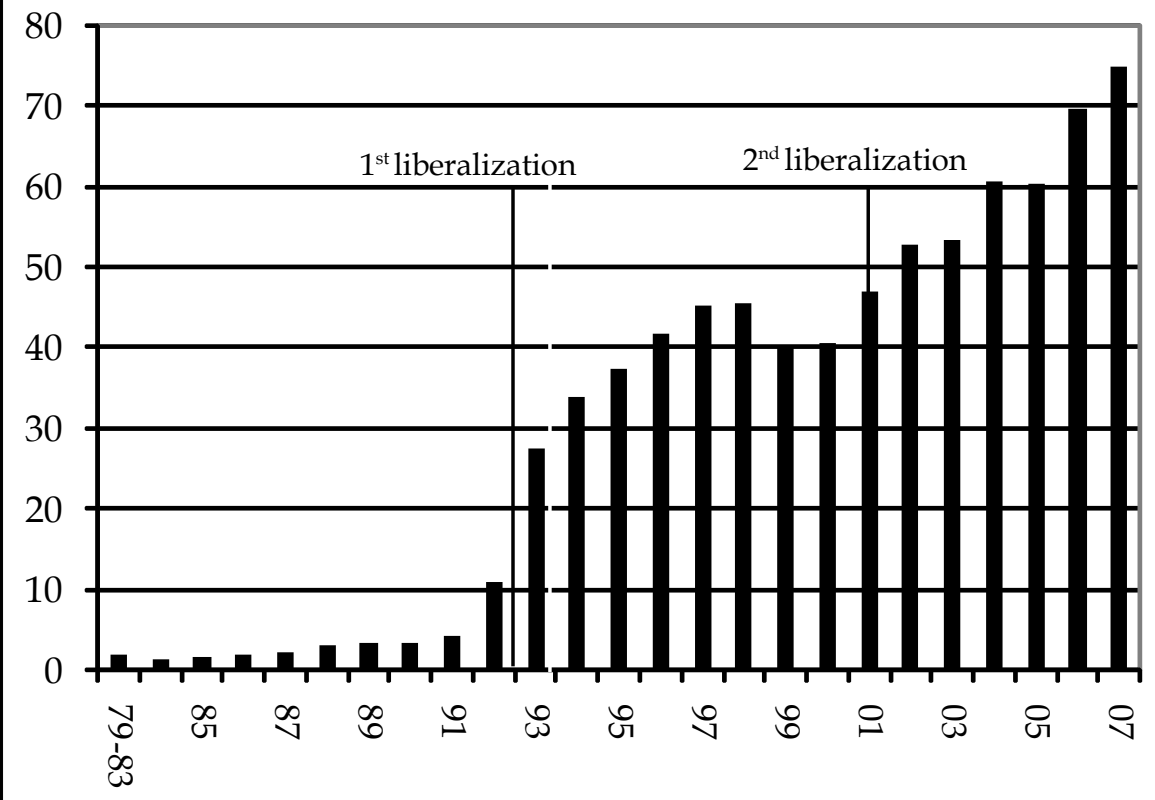

Source: China Statistical Yearbook, various.

some 300 million people will be over 65 . This is a vast underestimate of those needing some form of government support as state workers are required to retire at 55 for men and 50 for women. Without SOEs, what would support them?

TABLE 3: China's Aging Population

\begin{tabular}{|c|c|c|c|c|}
\hline & $\begin{array}{c}\text { Population (in } \\
\text { billions) }\end{array}$ & 0-14 years & 15-64 years & 65+ years \\
\hline 1995 & 1.21 & 327 & 808 & 76 \\
\hline 2000 & 1.26 & 328 & 845 & 87 \\
\hline 2010 & 1.35 & 293 & 956 & 104 \\
\hline 2020 & 1.43 & 287 & 989 & 214 \\
\hline 2030 & 1.48 & 278 & 989 & 214 \\
\hline 2040 & 1.49 & 287 & 950 & 252 \\
\hline 2050 & 1.47 & 211 & 962 & 300 \\
\hline
\end{tabular}

Source: World Bank, Asia Wall Street Journal, 15-17 June 2001, p. M1. 


\section{Foreign Investment}

Second, and in retrospect fraught with risk, the government had little choice but to increase its dependence on the non-state sector to create jobs. While minying, or enterprises managed by the people, were actively encouraged, foreign investment rules were liberalized for the second time since 2001 (the first great liberalization following the Tiananmen incident) as China negotiated its entry into the World Trade Organization (WTO) and capital began to pour in once again (see Figure 10) (Lardy 1992: 7577; Fung et al. 2002). Just how important FDI became can be seen in the employment data (see Figure 11).

FIGURE 11: Employment Trends SOEs vs. Private and Foreign Sectors, 1989-2003 (in thousands)

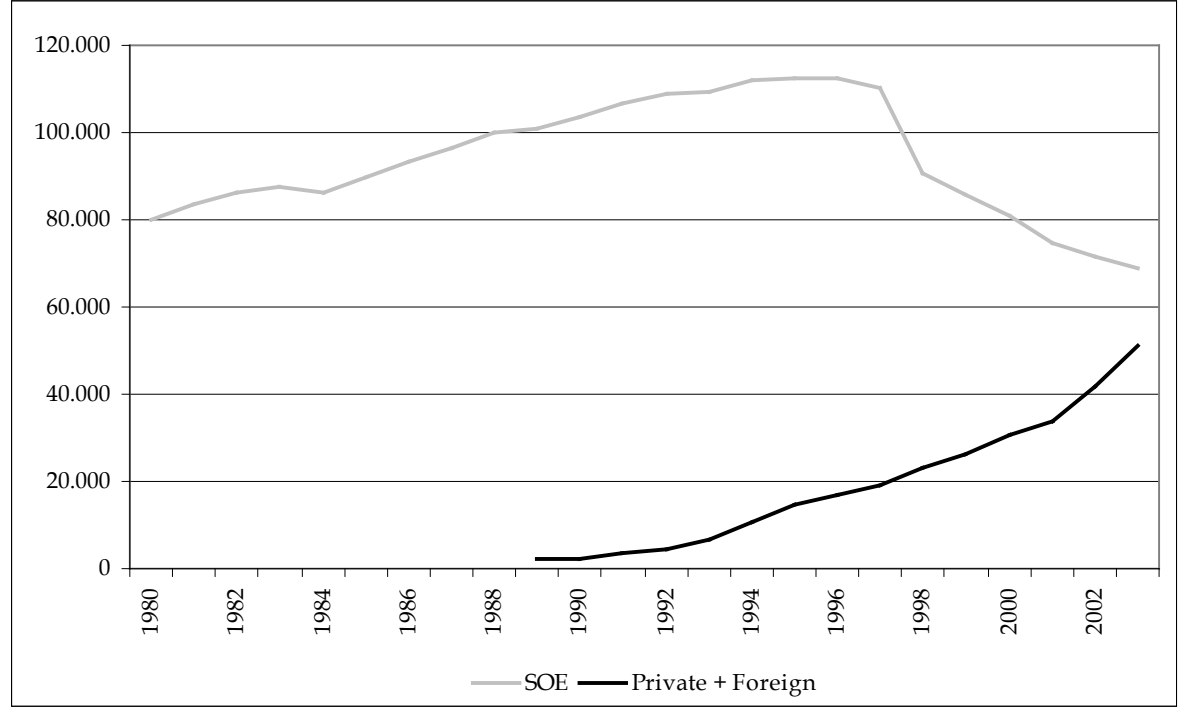

Through the end of 2003 the state-owned sector had shed nearly 44 million jobs while the private and foreign-invested sectors together had added over 52 million. But a look at the type of foreign investment vehicle might better illustrate the country's eagerness for foreign investment (see Table 4). As foreign investment began in the 1980s the dominant form of investment vehicle was, as discussed above, the Sino-foreign joint venture (JV). The type of JV is not important to this analysis, it was enough that it was a JV and that it was relatively difficult for foreign investors to establish wholly-owned companies in China until the late 1990s. As of 2000 wholly-foreign owned enterprises (WOFE) represented 47 percent of total FDI investment value and 54 percent of the number of all projects approved. Eight years later, in 2008, WOFEs constituted 78 percent of total FDI and 81 percent of all approved projects (see Table 4). 
Reliance on foreign companies to create employment opportunities while the state sector shrank was not the only risk created by China's FDI policies. The aggressive attraction of foreign investment also raised the country's exposure to the international trading system to levels exceptional within the global context. One indicator of an economy's involvement with the international economy showed that China was

TABLE 4: FDI by Investment Vehicle Structure

\begin{tabular}{|c|c|c|c|c|c|}
\hline & $\begin{array}{c}\text { EJV } \\
\text { (in \%) }\end{array}$ & $\begin{array}{c}\text { CJV } \\
\text { (in \%) }\end{array}$ & $\begin{array}{c}\text { WFOE } \\
\text { (in \%) }\end{array}$ & $\begin{array}{c}\text { FISE } \\
\text { (in \%) }\end{array}$ & $\begin{array}{c}\text { Total FDI } \\
\text { (in billions of US\$) }\end{array}$ \\
\hline 2000 & 36.2 & 16.1 & 47.4 & 0.2 & 40.3 \\
\hline 2001 & 35.1 & 13.1 & 50.9 & 0.9 & 46.4 \\
\hline 2002 & 28.4 & 9.7 & 60.5 & 1.3 & 52.4 \\
\hline 2003 & 29.1 & 7.2 & 63.1 & 0.6 & 52.9 \\
\hline 2004 & 27.1 & 5.1 & 66.4 & 1.3 & 60.5 \\
\hline 2005 & 24.2 & 3 & 71.4 & 1.4 & 60.3 \\
\hline 2006 & 22.5 & 4 & 73.4 & 0.6 & 65.8 \\
\hline 2007 & 20.9 & 1.9 & 76.6 & 0.7 & 74.8 \\
\hline 2008 & 18.7 & 2.1 & 78.2 & 1.0 & 92.4 \\
\hline
\end{tabular}

Source: US-China Business Council, www.uschina.org, 9 August, 2009.

Note: EJV - Equity JV; CJV - Contractual JV; WFOE - Wholly-owned foreign enterprise; FISE - Foreign-invested shareholding enterprise

more open and more exposed than any large economy in the world (see Table 5) (Lardy 1992: 150-55). Thus, the obverse side to investment and job creation was the development of this double-edged political risk-domestic reliance on foreign investment and economic reliance on foreign trade - that was not perceived until it was far too late.

\section{Stage 4: 2002-2008}

As the government considered how to fund a national social security scheme in the late 1990s, it found that the shareholding system, the cause of the problem, also offered a potential solution (Yuan Jian 2004:

TABLE 5: Comparative Foreign Trade Ratios, 2006

\begin{tabular}{|c|c|c|c|}
\hline Country & Trade Ratio & Country & Trade Ratio \\
\hline China & 67 & United States & 23 \\
\hline Denmark & 65 & Russia & 48 \\
\hline Finland & 69 & India & 32 \\
\hline Israel & 69 & Japan & 28 \\
\hline Korea & 72 & Brazil & 22 \\
\hline
\end{tabular}

Source: World Bank, World Development Indicators, 2008. 
198-202; 253-68). From the start, the SOE listing process had only been about raising capital, not privatization or better corporate governance. To drive that point home, a regulation made clear that the dilution of the state's holdings below 51 percent was forbidden. Consequently, at the start of the new century the state still held on average 66 percent of the shares of all domestically listed companies. It could, simply by selling some of these shares, raise significant sums of money, while still retaining absolute control of its SOEs.

\section{Old Shares for New}

Until 2001 the funding received from IPOs or share placements had come only from selling new shares, not old ones. The consequences of this were twofold: first, the proceeds of the IPO were retained directly by the issuer itself and could be used for corporate development. This was what investors wanted to see and was good. The second consequence was more ideological: the state would not be perceived as even suggesting that it would privatize its companies by directly selling down even a portion of its holdings. This was also good as it was the fundamental condition (along with the 51 percent rule) of proceeding. But that was before. Now conditions had changed and it was 2001. If the state could find a way around its ideological concerns to sell some of its existing shares as part of an IPO, then such proceeds could go to the state investor and not to the increasingly autonomous company management team and could be used as the state itself saw fit (Walter and Howie 2006: 207-09). These monies, then, could be directed to fund social security.

The National Social Security Fund (NSSF) was established in late 2001 to provide a funding source of last resort for locally sponsored social security schemes. Its principal sources of funding (see Table 6) were meant to be from the National Budget via the Ministry of Finance (MOF), the various national lotteries and, based on the CSRC proposal described below, proceeds from the outright sale of state-owned shares. The CSRC proposed that a modest 10 percent of all shares sold in IPOs or share placements be existing shares, not new shares, and that the proceeds be deposited directly in the accounts of the NSSF (see Figure 12). The timing of this proposal appeared to be perfect: the Shanghai Index had just hit an historic high of 2,000 points. But when the first IPOs under the new policy took place, the market immediately collapsed (see Figure 13). Over the next four years the securities industry went bankrupt and the state was forced to make good the investments of small retail investors at huge cost. The approach was abandoned just 
Carl E. Walter

TABLE 6: Trends in NSSF Funding Sources, 2000 - 2007

\begin{tabular}{|c|c|c|c|c|c|c|c|c|c|}
\hline $\begin{array}{c}\text { (RMB in } \\
\text { billions) }\end{array}$ & $\mathbf{2 0 0 0}$ & $\mathbf{2 0 0 1}$ & $\mathbf{2 0 0 2}$ & $\mathbf{2 0 0 3}$ & $\mathbf{2 0 0 4}$ & $\mathbf{2 0 0 5}$ & $\mathbf{2 0 0 6}$ & $\mathbf{2 0 0 7}$ & Total \\
\hline MOF & 20.0 & 47.4 & 30.4 & - & 17.1 & 10.0 & 38.6 & 10.0 & 173.5 \\
\hline $\begin{array}{c}\text { Sale of State } \\
\text { Shares }\end{array}$ & - & 12.2 & 8.8 & 0.4 & 4.7 & 8.3 & 11.4 & $12.5^{*}$ & 48.3 \\
\hline Lottery & - & - & 2.4 & 4.5 & 6.1 & 4.6 & 7.4 & 8.3 & 33.3 \\
\hline Total & 20.0 & 59.5 & 41.6 & 4.9 & 27.9 & 22.9 & 57.4 & 30.8 & 255.1 \\
\hline
\end{tabular}

Source: NSSF, Annual Reports 2000-2007, at www.ssf.gov.cn, various dates

Note: includes only RMB4.4 billion derived from listings or secondary offerings and, for the first time, RMB8.1 billion came from the over-the-counter transfer of state shares.

FIGURE 12: State Sells Ten Percent of Total Shares Offered in IPO

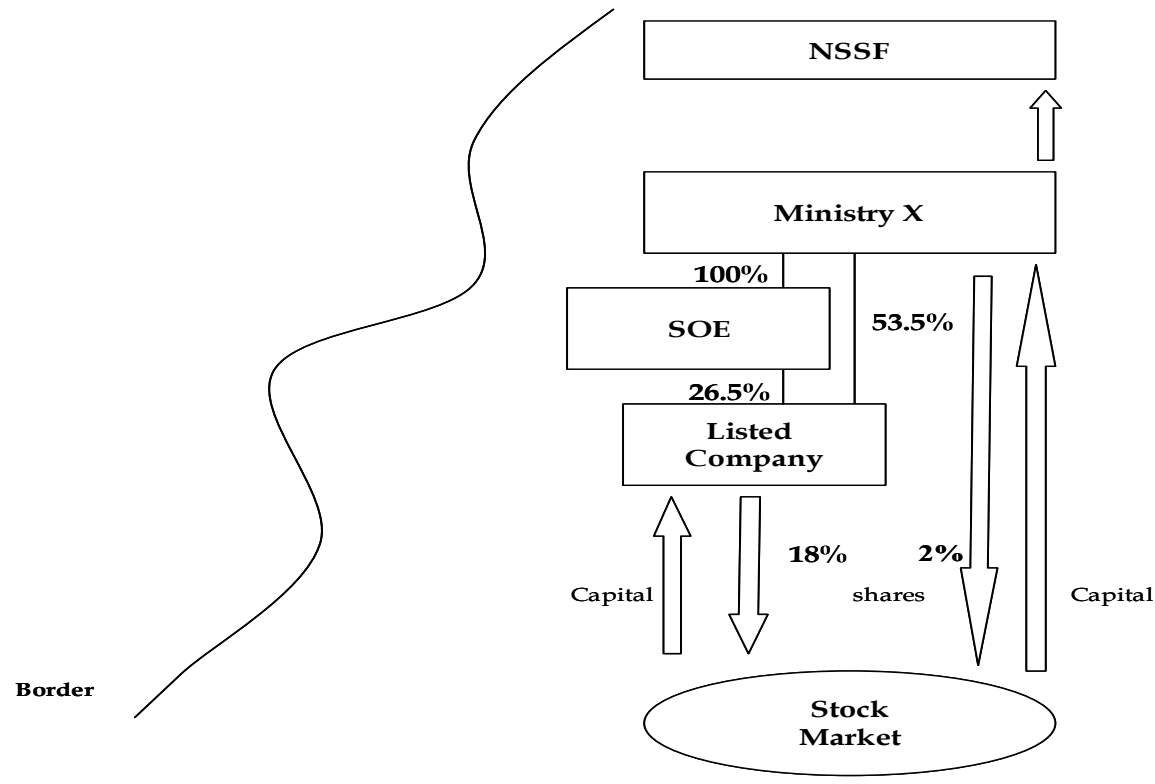

Source: China Statistical Yearbook.

months after it was announced (except for listings and placements in the international market). How did this modest and well-intentioned policy fail with such disastrous results?

\section{The Powers of Dilution}

First of all, domestic investors believed that the state would never privatize, that is, sell down its existing shares held in its companies (something the government had repeated over and again). Of course, if state-owned shares began to be sold into the market, the potential for significant dilution of listed share values existed. Based, however, on 
the understanding that such shares would remain unlisted, the market, the listed companies and investors simply came to ignore the huge 66 percent overhang of unlisted shares during the 1990s. As a consequence, a sort of informal social contract had been created. This, at least, was the argument that the interest groups used to ultimately prevent the government from diluting the value of their holdings. And how did these business groups arise? The stock markets had created them.

The markets had created the wealth and enhanced the political clout of the huge nearly autonomous national champions. The ministries or group companies that 'owned' the great listed companies did not support the idea that the shares they held, theoretically on behalf of the state, could be sold at the order of the state (e.g., the 2 percent sold by

FIGURE 13: Shanghai Index Performance, 1 October 1999-1 October 2005

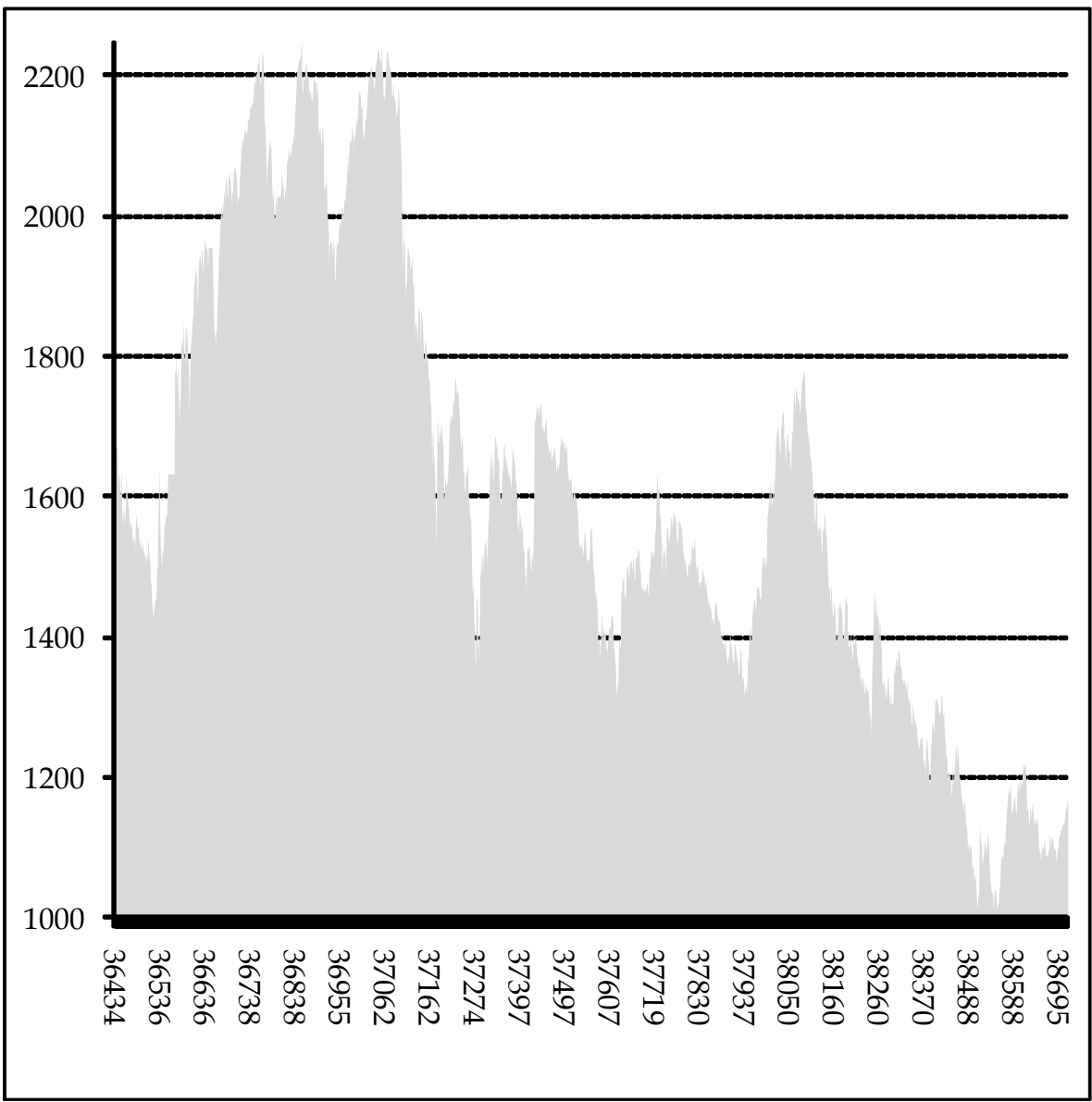

Source: Wind Information 
Ministry X in Figure 12). And if these shares were sold, they liked still less the fact that the proceeds would accrue not to themselves, but to another state entity, to wit, the NSSF. And to make this worse, the addition to the market of potentially huge volumes of such state shares would devalue their own companies' market capitalization as well as the stock positions their companies, or their subsidiaries, for example, the securities companies, might be holding (not to mention their personal holdings). These were the motivations behind their effort to put a halt to the CSRC's policy (Hu Shuli 2002: 6).

\section{The Consequences of Failed Welfare Reform}

Now, in 2008 and 2009, and after 30 years of 'reform and opening,' the absence of a viable national social security scheme has made itself felt as millions of workers in the foreign-invested, internationally exposed areas of the economy are being laid off due to the global recession. The ability of the oligarchic national champions to assert their own economic interests ahead of the national interest can be seen in the events of 2001. The Hu Jintao/Wen Jiabao government took office in 2003 explicitly seeking to rebalance the emphasis of economic development away from such groups. For example, in 2003 the SASAC was established to fill the void left by the elimination of the SAMB (Walter and Howie 2006: 219-22). But to date, SASAC has also been unable to assert itself. It has proven, for example, nearly impossible to access dividends paid by the investments it is entrusted by the State Council to manage! The struggle goes on.

\section{Looking Ahead}

The global crisis has further weakened the central government's hand against the interest groups: the economic stimulus package of unlimited loans plays directly into their hands. Moreover, despite efforts at controlling medical costs and relieving the burdens of farmers, Olympic hubris and the financial crisis are creating a cynical urban populace. This can be seen in their reaction to the burning of the CCTV Tower hotel building. Nor is it any secret who all the high-end shopping malls have been (and are being) built for. Despite the overwhelming power of China's sixtieth anniversary celebrations, bread and circuses may no longer be a viable option to build social unity: real economic growth and jobs are needed. At a time when the glow of the wildly successful Beijing Olympics has barely faded, a political struggle has broken out between, on the one 
hand, those who most benefited from the old outward looking regime and seek its continuation - it did produce growth - and, on the other, those who seek a more inwardly oriented socialist path.

Will there be a restoration of a far more statist political economy with American-style market forces suppressed or, more of what has been the case to date, a Wild West scenario where business groups are able to trump the government and money continues to be the be-all and end-all. American profligacy, after all, did greatly contribute to China's present wealth. Looking forward it is unclear what direction China will take in the wake of the global financial crisis. Without question, on the thirty-year anniversary of reform and opening, China is facing its greatest challenge since emerging from the Cultural Revolution in 1976 and successfully groping across the stones to find its way forward toward today.

Carl E. Walter is an investment banker living and working in Beijing. He holds a PhD from Stanford University and a graduate certificate from Beijing University.(carl.walter@jpmorgan.com)

\section{REFERENCES}

Cao, Erjie 1994. Zhongguo zhengquan shichang yanjiu yu zhanwang [Research and Prospects for China's Securities Markets]. Beijing: Zhongguo caizheng jingji chubanshe.

Cao, Lan 2001. 'Chinese Privatization: Between Plan and Market'. Law and Contemporary Problems 63(4): 16. Accessed from www.law.duke.edu/journals/63LCPCá, accessed June 19, 2009.

Fan, Yongjin et al. 2007. Zhongguo gushi zaonian suiyue 1984-1992 [The Early Days of China's Stockmarkets 1984-1992]. Shanghai: Renmin chubanshe.

Fung, K. C., et al. 2002. 'Foreign Direct Investment in China'. Accessed from http:/ / www.hiebs.hku.hk/working_paper_updates/pdf/wp1049.pdf, accessed May 17, 2009.

Gao, Shangquan and Sen Ye 1991. Systems Reform Handbook 1990. Beijing: China Reform Publishing House.

Garnaut, Ross, Song Ligang, Tenev, Stoyan and Yao Yang 2005. China's Ownership Transformation. Washington D.C.: International Finance Corporation.

$\mathrm{Hu}$, Shuli 2002. 'Disadvantaged Groups Should Stay Far from the Market'. Caijing, 20 October 2002.

Huang, Yasheng 2003. Selling China. Cambridge: Cambridge University Press.

Jiang, Ping 1997. Jinrong falu fagui quanshu [Compendium of financial laws and regulations]. xia Beijing: Zhongguo jingji chubanshe.

Lardy, Nicholas 1992. Foreign Trade and Economic Reform in China 1978-1990. Cambridge: Cambridge University Press.

Li, Liming and Cao, Renxiong 2007. 1979-2006 Zhongguo jinrong dabiange [1979-2006: The Great Changes in China's Finances]. Beijing: Zhongguo jinrong chubanshe.

Li, Zhangzhe 2001. Zhongyu chenggong: zhongguo gushi fazhan baogao [Success at Last: Re- 
port on the Development of China's Stock Markets]. Beijing: Shijie zhishi chubanshe.

Liu, Hongru 1992. 'Zhongguo guquan jiegou shiyan de ruogan wenti' [Several Problems of China's Shareholding Structure Experiments]. Renmin ribao, 23 June 1992, p. 5.

- 2003. Tansuo zhongguo ziben shichang fazhan zhilu [Exploring the Road to the Development of China's Capital Markets]. Beijing: Zhongguo jinrong chubanshe.

- 2008. Tupo - zhongguo ziben shichang fazhanzhilu [Breakthrough - the Road to the Development of China's Capital Markets]. Beijing: Zhongguo jinrong chubanshe.

Nolan, Peter 2001. China and the Global Economy. New York: Palgrave.

Walter, Carl E. and Howie, Fraser J.T. 2001. 'To Get Rich is Glorious!' China's Stock Markets in the ' 80 s and '90s. New York: Palgrave.

- and Fraser J. T. Howie 2006. Privatizing China: Inside China's Stock Markets 2nd ed. Singapore: John Wiley \& Sons.

Wang, An 2000. Guye nishangzuo [Mr. Shareholder, Go to the Head of the Table]. Beijing: Huayi chubanshe.

Wu, Jinglian 2003. Dangdai Zhongguo jingji gaige [Economic Reform in Contemporary China]. Shanghai: Shanghai yuandong chubanshe.

- 2004. 'Market Socialism and Chinese Economic Reform'. Paper submitted to the Institute of Economic Affairs, 2004 Round Table, 'Market and Socialism Reconsidered'. Available at bm.ust.hk, accessed April 5, 2009.

$\mathrm{Wu}$, Xiaoling 2008. Zhongguo jinrong gaige kaifang da shiji [Major Events in the Reform and Opening of China's Banking Sector]. Beijing: Zhongguo jinrong chubanshe.

Xiang, Huaicheng. 'Challenges Confronting National Social Security Fund'. Speech on December 14, 2005, at Hong Kong Open University. Accessed from http:/ / www. ssf.gov.cn/enweb/NewsInfo.asp?NewsId=543, accessed April 7, 2009.

Yuan, Jian 2004. Zhongguo zhengquan shichang pipan [Criticism of China's Securities Markets]. Beijing: Zhongguo shehui kexue chubanshe. 